EU-GUGLE:

\title{
A Sustainable Renovation for Smarter Cities from a Pilot Project
}

\author{
Naomi Morishita ${ }^{1}$, Michael Heidenreich ${ }^{2}$, Rosa Hemmers ${ }^{3}$, Maria Vankann ${ }^{4}$, \\ Tiina Sahakari ${ }^{5}$, Terttu Vainio ${ }^{6}$, Lorenzo Pagliano ${ }^{7}$, Martin Treberspurg ${ }^{2}$, Doris Österreicher ${ }^{2}$ \\ TUWien, Research Center for Building Physics and Sound Protection, \\ Institute for Building Construction and Technology ${ }^{1}$, \\ University of Natural Resources \& Life Sciences, Vienna \\ Department of Civil Engineering and Natural Hazards, Civil Engineering Institute, \\ Sustainable Constructions Working Group ${ }_{3}^{2}$, \\ SynergieKomm Agency for Sustainability and Innovation ${ }^{3}$ \\ City of Aachen, \\ Ecofellows Ltd., City of Tampere ${ }^{5}$, \\ VTT Technical Research Centre of Finland Ltd. ${ }^{6}$ \\ end-use Efficiency Research Group, Energy Department, Politecnico di Milano ${ }^{\dagger}$
}

E-mail: naomi.morishita@gmail.com, michael.heidenreich@boku.ac.at martin.treberspurg@boku.ac.at

\begin{abstract}
The European building stock is mature, and expanding cities need inclusive and innovative renovation solutions for all citizens while intensifying city densification. The European project EU-GUGLE aims to reduce primary energy consumption by $40 \%$ to $80 \%$ and increase renewable energy use by $25 \%$ through nearly zero energy building renovation models for initiating large-scale, Europe-wide replication in cities and communities. About $200,000 \mathrm{~m}^{2}$ of residential and public buildings are being refurbished by implementing a balanced mix of technical, socio-economic and financial solutions adapted to local needs. Six EU partner cities are participating, each revitalizing an urban district: Aachen, Bratislava, Milan, Sestao, Tampere, and Vienna. The comprehensive integrated approach used in EU-GUGLE is in line with the European Smart City initiative, and each participating city has created nearly zero-energy Smart City master plans based upon lowest energy thermal renovations coupled with innovative renewable energy services incorporating every aspect of smart district life. All stages of the planning, construction and post-occupancy phases of the large-scale district renewals are being documented, monitored and evaluated to create sustainable district renovation methodologies for "smart renovations for smart cities" to meet the objectives of the European Commission's Smart Cities and Communities Initiative for reducing $40 \%$ of greenhouse gas emissions within the European Union by 2020 . The paper outlines the approach each city has taken and highlights case studies of the individual solutions created in three of the six cities.
\end{abstract}

Keywords: smart city; social housing; low-energy renovation; renewable energies; pilot project

\section{Introduction}

With the growing urbanization trend, European cities are increasingly facing challenges to cope with the demand in providing adequate living spaces for the rising number of inhabitants whilst ensuring a high quality of life. At the same time climate change and limited resources provide the framework for setting ambitious climate goals for the member states of the European Union. Energy efficiency and the integration of renewable energy systems can be seen as the key elements in reducing energy demand by fossil fuels, however in the urban context energy is one of these key elements within a more complex structure. In a Smart City the goal is the optimization of the overall system of a city, by ensuring the interaction of the different sectors: energy infrastructure, the built environment, urban design, industry and mobility must be planned together in an integrated approach. Communication technologies subsequently allow these sectors to interact, thus ideally providing an optimum in terms of smart use of energy and resources. The involvement of stakeholders in this development process is crucial for a successful implementation, as adaptations are mostly carried out in existing cities or city quarters. Refurbishment actions play a particular important role in the smart city context, as most of the buildings we will inhabit in the future are already being built.

The EU-GUGLE project aims at providing replicable strategies and concrete solutions for large-scale refurbishment actions across Europe. EU-GUGLE stands for "European cities serving as Green Urban Gate towards Leadership in sustainable Energy" and is a European project taking place from 2013 to 2019 involving six partner cities in six countries: Aachen (Germany), Bratislava (Slovakia), Milan (Italy), Sestao (Spain), Tampere (Finland), and Vienna (Austria). The National Renewable Energy Centre in Spain (CENER) coordinates the project and consortium members are from Spain, Austria, Belgium, Finland, Germany, Italy, 
and Slovakia. Project partners in each city are from local government, public (social) and private housing estates, tenant associations, research centers and universities, utility companies, and private energy consulting companies. Three further cities are participating actively as associated municipalities so they can integrate any lessons learned into their own plans for smart eco-building projects and districts. Gothenburg's district Hammarkullen (Sweden), Plovdiv (Bulgaria), and Gaziantep (Turkey) are the "associated cities" attending replication workshops and having direct access to experts in the field who have experience adapting large-scale building refurbishments at a district level.

Each demonstration city has chosen to revitalize a specific district, setting a benchmark for both the city itself, and an example for other cities to sustainably revitalize their building stocks incorporating renewable energy sources and reducing primary energy consumption in the range of $40 \%$ to $80 \%$ through the implementation of nearly zero energy building renovations (Manteca, 2015). The revitalization strategies for each city are in line with the European Smart City Initiative. Roughly $200,000 \mathrm{~m}^{2}$ of residential and public buildings are being revitalized within the framework of the EU-GUGLE project. This project has received funding from the European Union's Seventh Framework Program for research, technological development, and demonstration under grant agreement No ENER/FP7EN/314632/EU-GUGLE.

The building typologies for renewal within the EU-GUGLE project are $19^{\text {th }}$-century and early $20^{\text {th }}$-century buildings, and large post-war housing developments mainly from the 1950's to the 1980's. Often the tenants and homeowners are from marginalized social groups such as low-income families, immigrants, and senior citizens. The integrated design process involves many stakeholders with decisions being made jointly by housing corporations, tenants, designers, and civil servants. Preliminary results among the participating cities have shown how the site-specific concepts and integration strategies may be deployed using an interdisciplinary approach and with an innovative and effective mix of strategies ranging from involving social groups and cooperating closely with communal authorities towards satisfying the majority of building users' needs.

\subsection{Overview of EU-GUGLE in Each Pilot City}

The project results form the basis for comprehensive "smart renovation strategies" to be easily transposable to other municipalities across the European Union. After successful implementation and testing of the renewal strategies during the realization phase of EU-GUGLE, the methodology is being applied to districts in three other associated partner cities who are a part of the "replication campaign" (Manteca, 2015). This paper gives background information on the participating districts, illustrates the applied concepts, and presents preliminary results from the implemented measures.

\section{Involved Districts}

The planned revitalizations within the EU-GUGLE project complement the master plans for each city that are for the year 2020 and beyond. All participating cities aside from Sestao have a Sustainable Energy Action Plan (SEAP) to be implemented as a part of the Covenant of Mayors commitment to local sustainable energy (Covenant of Mayors, 2009). Where possible, the actions within the EU-GUGLE project align with the vision, roadmap, and action plans contained within each city's SEAP. The purpose of all district revitalizations is to highlight the positive impact of large-scale sustainable energy-efficient renovations integrating the production, distribution and use of renewable energies with the intention to replicate the results in the pilot city's other districts of the cities and also in other replication cities (Heidenreich et al., 2015).

Each of the participating districts has a unique context of socio-economic background, size, climate, ownership scheme and building typology. However, a common element to all buildings in all districts is the requirement for urban revitalization.Table 1 summarizes the pilot districts' refurbishment measures (Heidenreich et al., 2015). 
Table 1: Refurbishment characteristics in the districts (Heidenreich et al., 2015).

\begin{tabular}{|c|c|c|}
\hline City District & Building Types & Age of Building Stock \\
\hline Aachen Nord & Residential apartment blocks & $\begin{array}{l}\text { Historical buildings from } \\
\text { the } 1920 \text { s to } 1930 \text { s, and } \\
\text { buildings from the } 1970 \text { s }\end{array}$ \\
\hline $\begin{array}{l}\text { Bratislava West } \\
\text { and Center }\end{array}$ & $\begin{array}{l}\text { Low-rise and high-rise residential } \\
\text { apartment blocks }\end{array}$ & 1930s, 1950s, and 1980s \\
\hline Milan Zone 4 \& 5 & Low-rise residential and a child care centre & $1980 s$ \\
\hline $\begin{array}{l}\text { Sestao Txabarri } \\
\text { / El Sol }\end{array}$ & Low-rise social housing & 1890 s to 1930 s \\
\hline $\begin{array}{l}\text { Tampere } \\
\text { Tammela }\end{array}$ & $\begin{array}{l}\text { Privately owned residential apartment } \\
\text { buildings }\end{array}$ & 1960 s to 1980 s \\
\hline Vienna Penzing & $\begin{array}{l}\text { Mixed social housing and privately owned } \\
\text { low-rise residential apartment blocks }\end{array}$ & 1950 s to 1970 s \\
\hline
\end{tabular}

The following sections describe the participating districts in greater detail.

\subsection{Aachen, Germany}

Aachen has a total area of $160.83 \mathrm{~km}^{2}$ and is situated on the western German border to Belgium and the Netherlands. Aachen has a strong focus on science and education with a large student body of more than 50,000 students, representing a fifth of the total population of 250,000 inhabitants (Vankann, 2015). The Aachen North district is a heterogeneous area with a mix of new and historic industrial, public and residential buildings (Hemmers, 2015) Due to developments during the last 80 years, many residential buildings are listed buildings. As a result, the district master plan focuses on revitalizing and improving the attractiveness of the district. Aachen North has a total area of $3 \mathrm{~km}^{2}$ with a population of 15,500 inhabitants. It is part of a multiyear urban development program called the Aachen North Social City (Soziale Stadt Aachen-Nord) wherein the efficiency of building envelopes are thermally upgraded, building plant systems are renewed and the energy infrastructure is being revitalized (Hemmers, 2015). Approximately 1,500 of the district residents, representing $10 \%$ of the Aachen North population, are directly involved in the EU-GUGLE project. The pilot buildings are owned by the City of Aachen (75\%) and by GEWOGE, a public housing company (25\%), and the building locations can be seen in Figure 1.

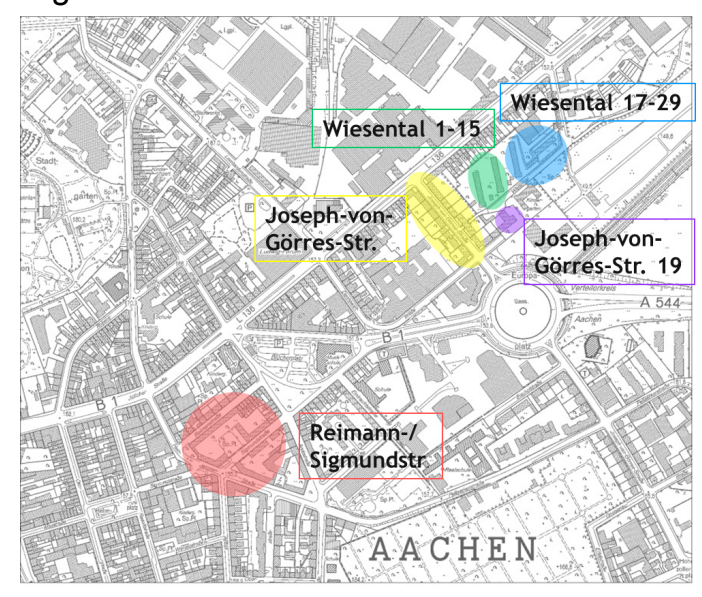

Figure 1: Aachen's Smart District, Aachen Nord (City of Aachen, 2015a).

\subsection{Bratislava, Slovakia}

Bratislava is the capital and largest city of Slovakia with a total area of $367.58 \mathrm{~km}^{2}$. Located in the southwest part of the country, it is close to the Austrian, Hungarian and Czech borders. Bratislava straddles both sides of the Danube River and occupies the left bank of the Morava River. The city is divided into five districts and 17 boroughs with a population of circa 420,000 inhabitants and a population density of 1,161 inhabitants $/ \mathrm{km}^{2}$. It is the political, cultural, and economic center of Slovakia. About $20,000 \mathrm{~m}^{2}$ of residential buildings in two districts representing the typical Bratislava building stock have been selected for the project. The pilot districts located in the city center and the western part of Bratislava are shown in Figure 2. Most buildings are connected to the district heating network and are privately-owned (Heidenreich et al., 2015). 


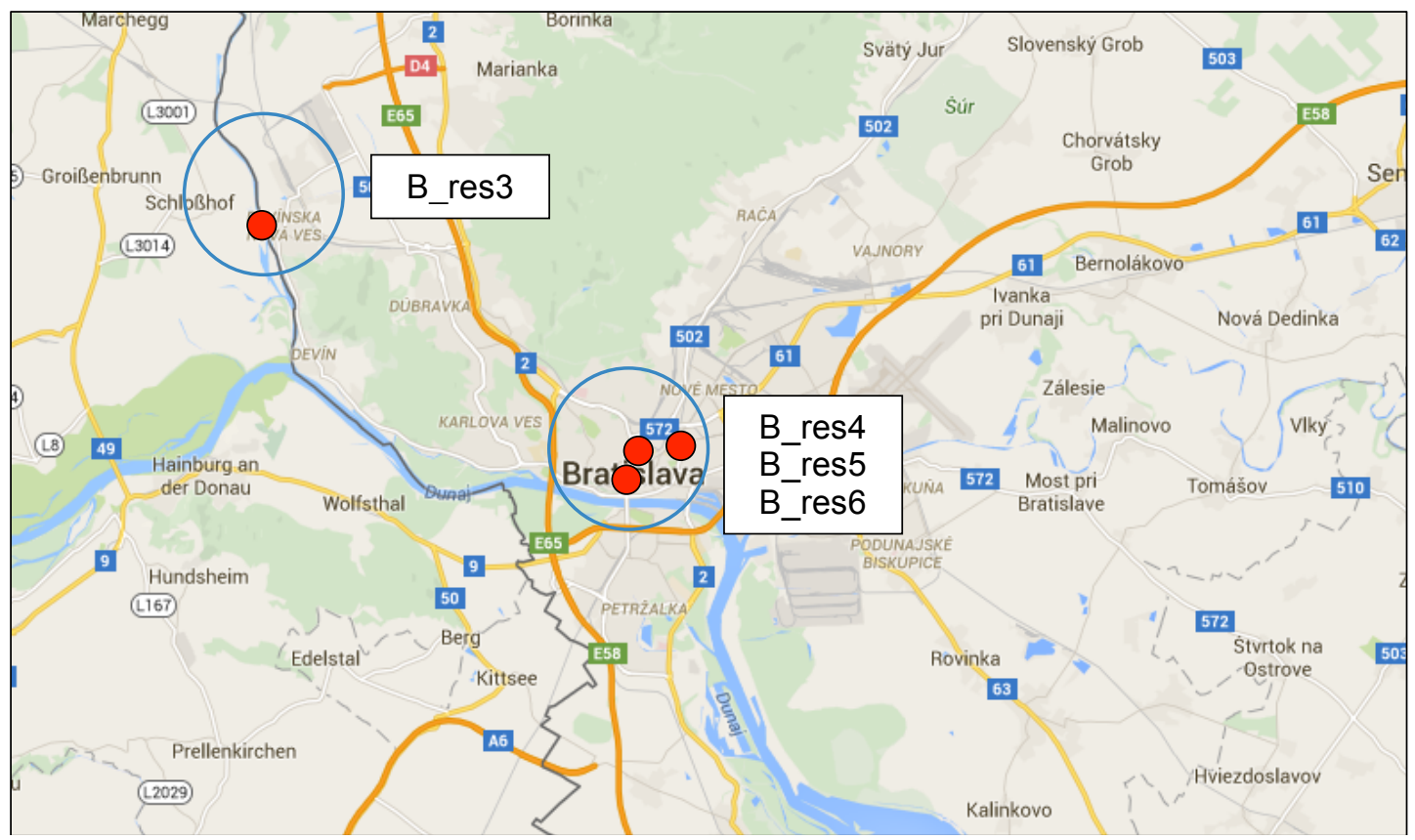

Figure 2: Bratislava's smart districts in the city center and west side of the city (Grünner, 2016).

\subsection{Milan, Italy}

Milan is the second largest city in Italy with a total area of circa $182 \mathrm{~km}^{2}$ and is Italy's main commercial, industrial and financial center with a population of circa 1.35 million. It is the capital of the Lombardy region and is part of the European Backbone region, the curved area in Europe extending from the United Kingdom to northern Italy with the highest population and industrial densification (Faludi, 2015; Hospers, 2003). Milan is structured into nine administrative districts; Zones 4 and 5 are involved in EU-GUGLE project. In the last two years, the city has developed energy and environmental, and sustainable mobility plans. Both plans have been subject to public debates with the population and stakeholders, and the plans have benefitted by the experience gained via EU-GUGLE and other ongoing EU projects. The municipal building regulation has been updated with inclusion of incentives for high efficiency buildings. Waste separation of organic material has been introduced in one district after the other; now it is implemented in the entire city. As a result, Milan citizens are now separating more than $50 \%$ of urban waste, one of the highest shares in Europe. The EUGUGLE project constitutes an important experience for the municipal building department. A group of department architects and engineers work together to create integrated designs with the scientific assistance of the eERG group of Politecnico di Milano. The municipal architects and engineers have gained experience in innovative technologies and design methods through this process. As a result, they will be in charge of promoting efficiency and comfort in the upcoming projects of the city. Zone 4, located in the southeastern part of the city, has an area of $21 \mathrm{~km}^{2}$ and is participating in the project. Zone 4 has a population of 152,300 inhabitants with a typical density for the city of 7,200 people per $\mathrm{km}^{2}$. Figure 3 shows the pilot buildings in the EU-GUGLE project in relation to public transit and the co-generation plant. 

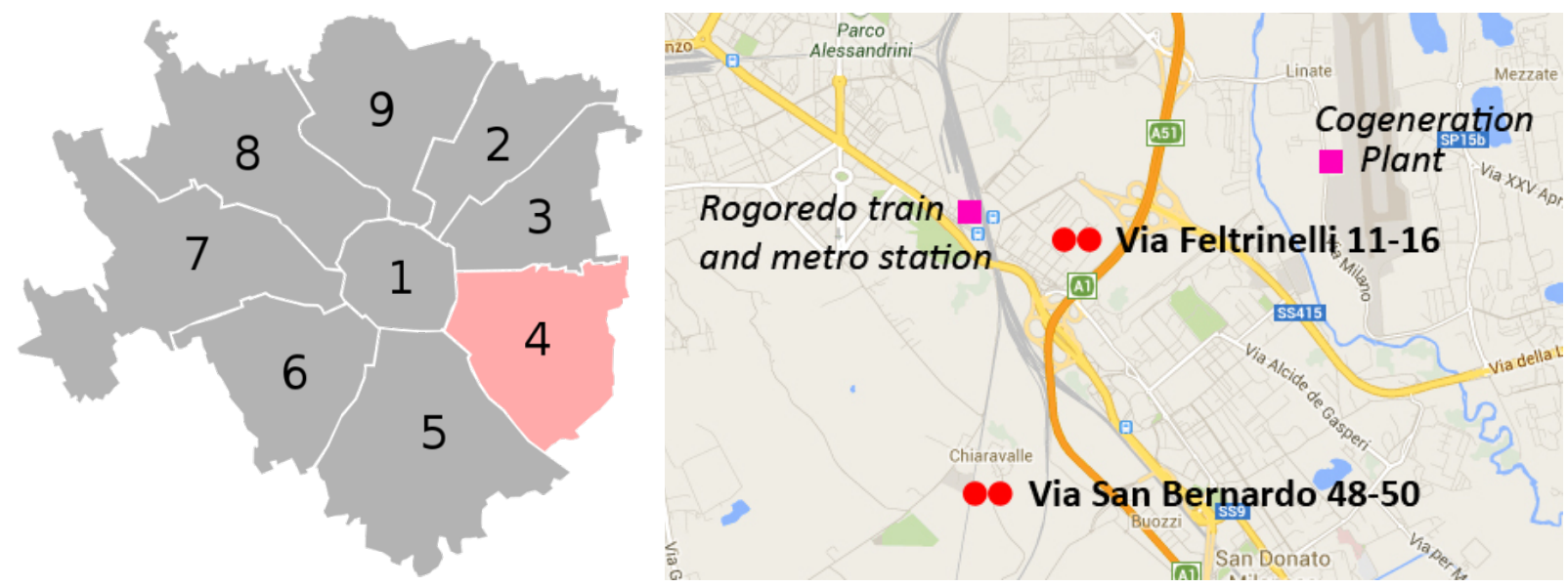

Figure 3: Milan's smart district, Zone 4, left; participating residential buildings in Rogoredo/Santa Giulia, right (Sangalli, 2016).

\subsection{Sestao, Spain}

Sestao is a post-industrial municipality located $11 \mathrm{~km}$ from Bilbao City, on the left bank of the Estuary of Bilbao. It was on the riverbanks where much of the Biscay municipalities were developed during the $19^{\text {th }}-$ century industrial boom. Sestao has an area of $3.5 \mathrm{~km}^{2}$, where $0.9 \mathrm{~km}^{2}$ is devoted to residential use and the rest are industrial areas. Since 1995, Sestao has been undergoing a deindustrializing process heavily impacting the local economy. Sestao currently has an unemployment rate of circa $30 \%$, and the pilot district in the city center has an even higher unemployment rate of 40\%.1,300 inhabitants live in the city center district. The early $20^{\text {th }}$-century residential building stock in this district borders an industrial area. The 258 residences, with a total area of $19,008 \mathrm{~m}^{2}$, are timber construction and range from 80 to 100 years in age. The dwellings have decayed over time. This area is the most affected by the deindustrialization process. Eight groups of housing estates are participating in the pilot project as outlined in Figure 4. Ownership is primarily by publiclyowned housing corporations (Heidenreich et al., 2015).

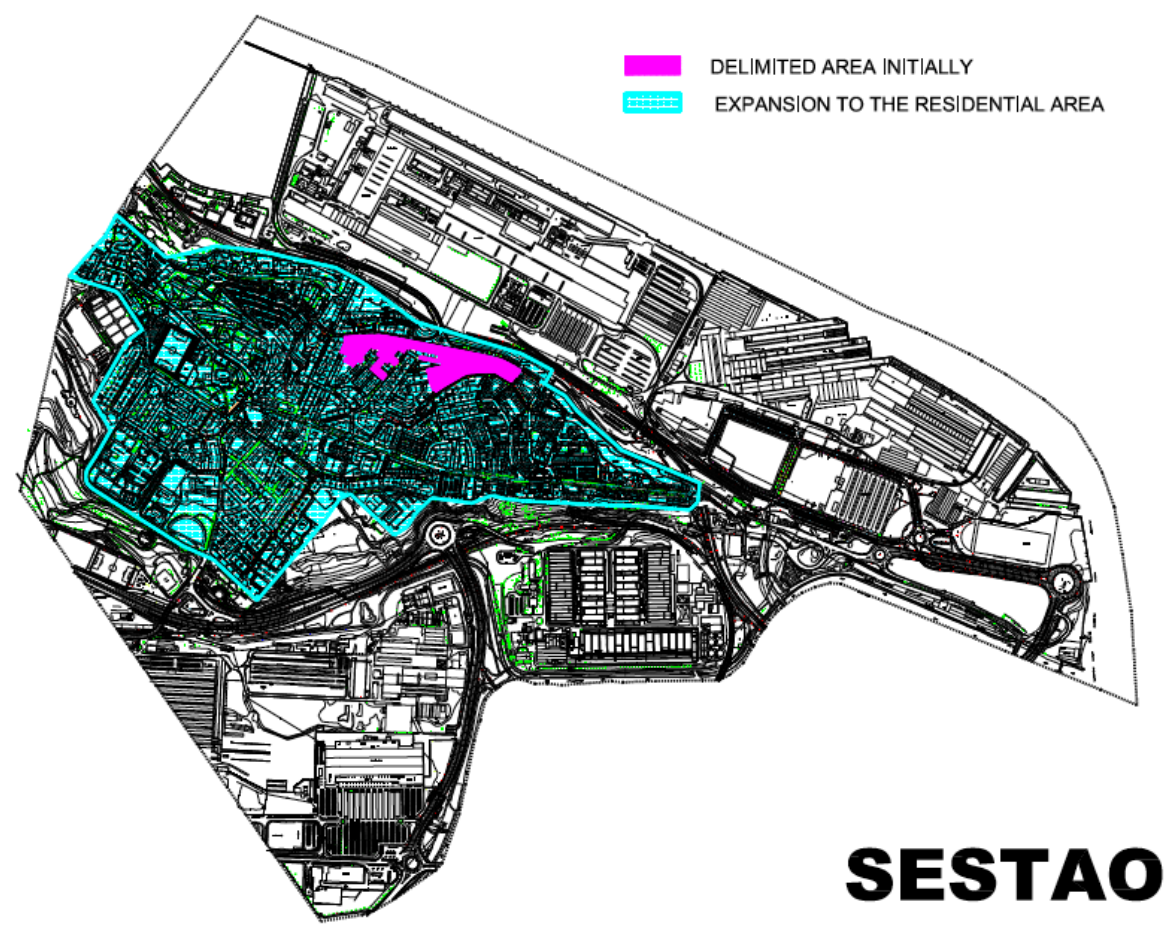

Figure 4: Sestao's smart district (Garbisu, 2016).

\subsection{Tampere, Finland}

Tampere is the third largest city and is the second largest growth center in Finland. Tampere is also the largest inland city in the Nordic countries with 225,433 inhabitants (Official Statistics of Finland, 2016). It is located on the banks of Tammerkoski Rapids, between the Näsijärvi and Pyhäjärvi Lakes. The EU-GUGLE demonstration project takes place in Tammela, which is a sparsely built traditional residential area located 
adjacent to the city center and the railway. Typical district characteristics include the traditional grid plan, vivid market square, and parks. Tammela requires building refurbishments and has a large potential for infill development.

Tammela has a population of 6,337 inhabitants and is primarily occupied by retirees. The Tammela building stock was mostly constructed from the 1960s to the 1980s. The residences as well as the building sites are privately owned. The majority of occupants are fixed-income retirees, young couples, and students. 560 inhabitants occupy 400 residences (circa 30,000 $\mathrm{m}^{2}$ ) in the eight demonstration buildings as seen in Figure 5.

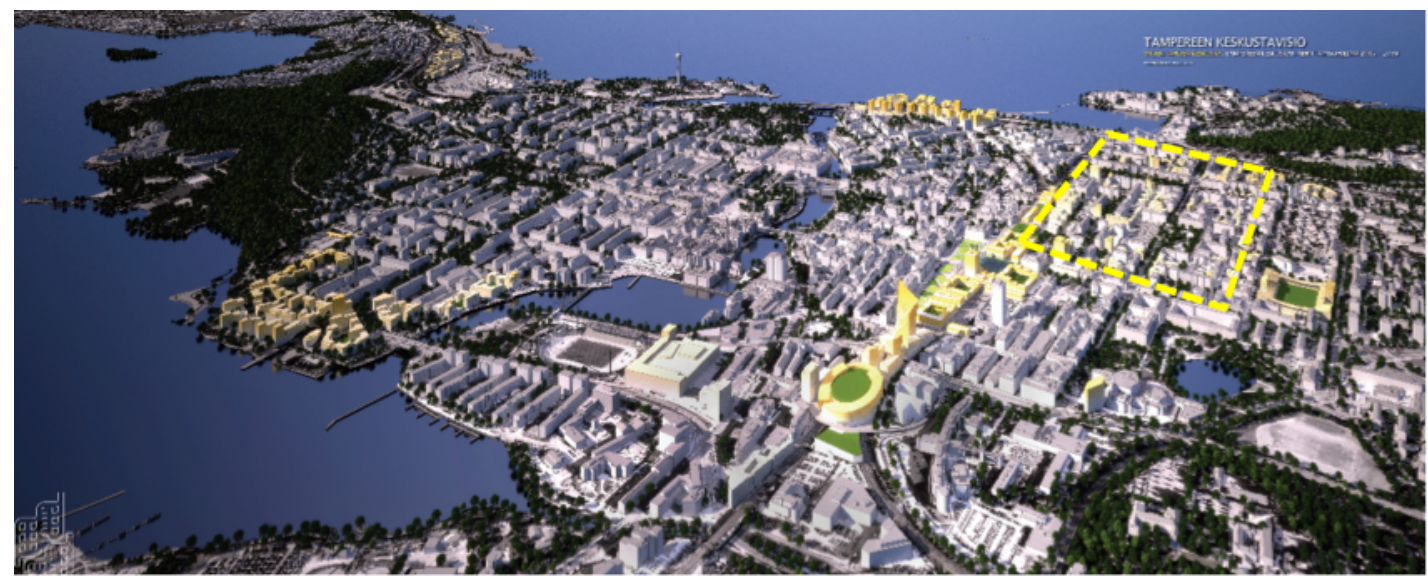

Figure 5: Tampere city center vision with smart district Tammela marked in yellow. Source: Tampere city center development vision, Tampere City Center Development Program 2015-2030 (Arkkitehdit MY, 2015).

\subsection{Vienna, Austria}

Vienna, the Austrian capital, is located near the eastern border of Austria close to Slovakia and Hungary. Vienna has 23 administrative districts. The participating pilot district is Penzing, the $14^{\text {th }}$ District located in the western part of Vienna as seen in Figure 6 . The total area of the district is $33.96 \mathrm{~km}^{2}$ with $60 \%$ covered by green space and the Viennese Woods. All participating demonstration buildings currently show a high energy demand and urgently need the foreseen renovation. The main foci are the efficient refurbishments of rental apartments with $67,220 \mathrm{~m}^{2}$ gross floor area, the use of prefabricated façade elements, the intelligent integration of renewable energy in buildings, and realization of suitable complementary measures to create a high-quality city district.

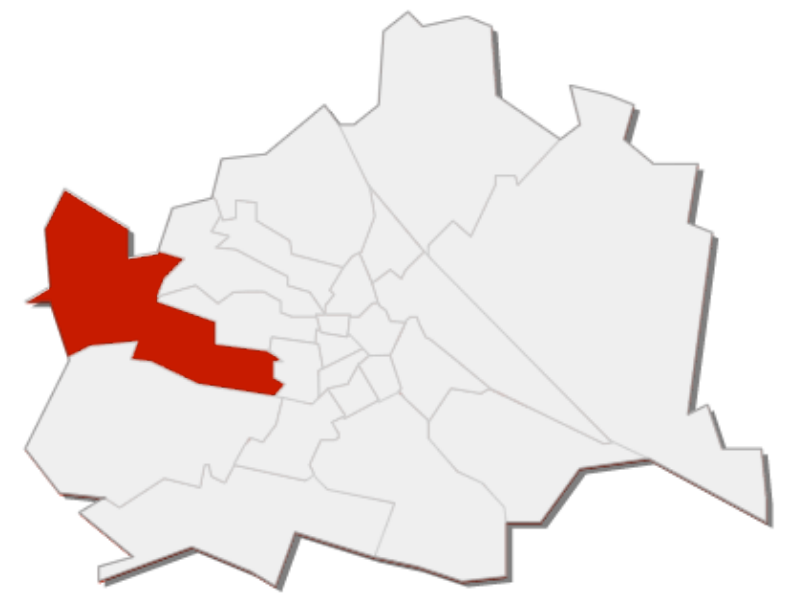

Figure 6: Vienna's Smart District, Penzing is shown in red (City of Vienna, 2016).

\section{Concepts in the Smart Districts}

The EU's strategy is to reduce greenhouse gas emissions by $20 \%$ from 1990 levels, increase renewable energy use by $20 \%$ and improve energy efficiency by $20 \%$ (European Commission, 2015). Five of the six EUGUGLE partner cities have signed the Covenant of Mayors (CoM) (Covenant of Mayors, 2009) and established their SEAPs as part of their pledge to the CoM also corresponding to the goals of the EU-GUGLE project.

The concepts described in the following sections outline the responses by local regulatory bodies to meet individual citizen requirements in the three most advanced partner districts of EU-GUGLE: Aachen North, and Tampere Tammela, and Vienna Penzing. 


\subsection{Aachen's Smart City Concepts}

Aachen has been developing energy efficiency and climate protection policies for more than 20 years. Aachen participates in the European Climate Alliance, Covenant of Mayors and the Mayors Adapt Initiatives. The combined initiatives influence the strategies for sustainable mobility, energy efficient building refurbishments, and renewable energy network expansion have been published in Aachen*2030 Master Plan (Stadt Aachen, 2012). The developments in the Aachen North district are underway with future development steps outlined in the "City Center Concept 2022" (Pflüger, Pflüger, Lemaire, Engel, \& Ruppert, 2015). Aachen has doubled their commitment to the European Union's 20-20-20 pledge, aiming for $40 \%$ greenhouse gas reductions by 2020 and increasing renewable energy systems integration by $40 \%$.

The climate protection concept focuses upon building energy conservation and thermal renovations combined with highly efficient building service systems. For Aachen, renewal of building plant services in building renovations is a central instrument in reaching the goal of reducing local $\mathrm{CO}_{2}$ emissions. Aachen aims to increase the residential refurbishment rate to two to three percent, above the German national average of one per cent. To encourage citizen participation, information campaigns to educate homeowners and business owners about the advantages of energy efficiency and renewable energy use are being conducted through direct mail, information events and activities. The altbau plus Information Centre was opened in 2004 for encouraging citizen participation in the transformation process to a sustainable, energy-efficient Aachen. The strategic implementations of advisory work are successfully being developed in Aachen North and will be expanded and applied to the city center in the near future.

Sustainable transport is the third main issue in Aachen's smart city concept encompassing thermal building renovations and renewable energy expansions. The sustainable transport plan aims to reduce car use by increasing the combined network of public transit, optimizing the cycling infrastructure and e-bike rentals, and developing a combined mobility platform (Stadt Aachen, 2012). All considered measures are being implemented in the pilot project in Aachen North.

\subsection{Bratislava's Smart City Concepts}

The SEAP by Bratislava embodies the smart city concepts for the short and medium terms to reduce carbon dioxide emissions. Bratislava also participates in the Covenant of Mayors. The action plan is an elaboration of the city vision of economic and social sustainability from 2010 to 2020 (City of Bratislava, 2013). The SEAP by Bratislava foresees implementation measures in the sectors of transportation, public lighting, and decreasing energy consumption in civic buildings coupled with decreasing energy consumption and related energy costs. The district heating system provides heat for both room heating and DHW for the majority of the urban apartment buildings. Bratislava is not a stockholder of the heat production utilities; therefore, it does not influence the price, production or supply of heating energy and domestic hot water.

Financing from the state housing development fund (ŠFRB) is focused on funding thermal building renovations such as substantial renovations. However, there are no direct financial promotion schemes for deep renovations including substantial renewal of technical systems or the use of renewable energy resources such as photovoltaic and/or solar thermal collectors. The local condominium associations present renewable energy system (RES) solutions to the homeowners for adoption. The location of buildings in assigned urban zones present challenges to some technologies using RES.

\subsection{Milan's Smart City Concepts}

The environmental protection goals were reinforced in the last years by public consultations, which showed a high demand by citizens of natural resources conservation, sustainable mobility, and a higher quality urban environment. The EU-GUGLE activities are considered as an important test for the application of the energy and mobility plans approved by the city, which need to be fully deployed in the next years. A zone at the border of Districts 4 and 5 has been chosen for the implementation of the EU-GUGLE pilot. The building envelopes of three residential social housing building blocks and a childcare center are undergoing thermal retrofits with high efficiency building services aimed at large improvements in energy efficiency, comfort, and indoor air quality. Prefabricated elements have been developed and tested on a small-scale with the support of industrial third parties. The prefabricated elements are comprised of decentralized mechanical ventilation systems, high-efficiency low noise ventilation fans, extremely compact heat exchangers for heat recovery, air flow controls based on occupancy, advanced glazing, and movable solar shading (Pagliano, Armani, Sangalli, Causone, \& Pietrobon, 2016).

\subsection{Sestao's Smart City Concepts}

Sestao began to revise their municipal master plan in the late 1990 s to reconvert the former industrial sectors into sustainable new districts. Shipbuilding and steelmaking were the primary industries until the 1970s, and many of the industrial buildings have been unused since the 1980s. Key points of the sustainable development plan include environmental regeneration of the urban edge, energy efficiency improvements of municipal services, sustainable mobility promotion, and the measures aligned with the EU-GUGLE project promotion of energy-efficient building renovations incorporating renewable energy sources, and recyclable and environmentally-friendly building materials to reduce greenhouse gas emissions. The measures within the 
master plan are scheduled for completion by 2020. Social inclusion is also an essential part of the sustainable development plan, as the reconverted industrial buildings will provide new commercial, social and cultural facilities improving the quality of life for the inhabitants of the pilot districts (Heidenreich et al., 2015).

The activities in the EU-GUGLE project complement the activities of three other European sustainability projects in Sestao (Sestao Berri S.A., 2016a). Sestao Berri 2010 is a joint partnership between the Town Council of Sestao and the Department of Employment and Social Services of the Basque Government and leads all four projects in Sestao (Sestao Berri S.A., 2016b).

\subsection{Tampere's Smart City Concepts}

The first target in Tampere's City Strategy 2025 is for Tampere to take a pioneering role in climate policy (City of Tampere, 2012). The 2025 target is to transition to a low-carbon city with greenhouse gas reductions of $40 \%$ below 1990 levels. The key challenge is to focus on ways to make land use, buildings, and traffic systems sustainable. The second priority is to increase heating energy efficiency. District heating is responsible for roughly a third of greenhouse gas emissions. The third key action area is to reduce electricity consumption. Concrete measures include constructing new energy-efficient buildings, improving the energy efficiency of existing buildings, increasing the share of renewable energy sources in local combined power and heat production, replacing cars running on fossil fuel with electric vehicles, and replacing mercury street lighting with intelligent LED lighting. The ECO2 Project ran from 2010 to 2015 as a platform to implement both the changes and sustainable approach to all city activities (City of Tampere, 2013). The name is an abbreviation for "Eco-Efficient Tampere 2020" and acted as an expert unit providing ecological and energy efficient solutions working together with cooperation partners. Now the work continues in co-operation with the energy efficiency and/or climate experts in different city departments and the work is coordinated by the Sustainable Community Department.

In the City of Tampere, every employee is responsible for sustainable energy uses in his or her work. The city uses financial incentives to stimulate the citizens to become involved in sustainable energy uses, e.g. employees qualify for rental discounts if a building is very energy efficient. The city provides free energy information services, mobility management, and organizes several gratis events for citizens throughout the year to stimulate sustainable actions. An information campaign is also a large part of the Tammela EUGUGLE strategy to reduce energy consumption.

An important aspect of Tampere's environmental strategy is the alignment of various program goals. The eight municipalities within the City of Tampere have adopted a joint regional climate strategy in 2010 . ECO2 also aligns with the European Union's Covenant of Mayors SEAP, signed in 2009 ensuring consistency in energy efficiency, environmental policies, and visions at district levels (City of Tampere, 2012).

\subsection{Vienna's Smart City Concepts}

Previously, individual regulatory and non-regulatory incentives were implemented in Vienna including voluntary measures, coordination mechanisms, and partnerships for achieving national environmental and economic goals. The EU-GUGLE project builds upon the previous incentives and complements the measures by adopting a holistic cross-sectional approach considering socio-economic issues, direct involvement of stakeholders from different interest groups, and a common performance framework based upon an accurate mix of statistical and empirical data. The activities within the EU-GUGLE project build upon the Viennese Smart City Wien Roadmap for 2020 and beyond, whose content is based upon a multidisciplinary stakeholder process which included participants from the city municipality, research, education, industry, and citizens, and was carried out from 2011 to 2012 (Vienna City Administration, 2014). Important trends and scenarios based on systems thinking were developed during the process, whereby the interrelationships between various elements within a system are explored to understand the system as a whole. The bottom-up approach ensures that the outcome and subsequent vision and strategy development have been widely accepted. Following the Roadmap, the Smart City Wien Framework Strategy was developed to provide a conceptual document which includes detailed measures in three main objectives to ensure a sustainable and holistic approach: Resources (objective: highest possible resource preservation), Innovation (objective: innovation leadership through cutting-edge research, a strong economy, and education), Quality of living (objective: assurance of top-level quality of living (Vienna City Administration, 2014).

The systems thinking approach has been carried over from Vienna to all other participating cities in the project to define effective interventions, structure procedures and information dissemination and to prepare project results towards replication measures (Heidenreich et al., 2015).

The master plan for the Vienna Penzing district was redefined in 2012 to align with regional, national, and European environmental goals while simultaneously considering energy efficient renewable technologies suited to individual user needs within the district. The district master plan is based upon the Smart City Vienna objectives: urban densification, energy-efficient renovation and new building construction, sustainable mobility, increased use of renewable energies, and energy-efficient occupant behavior (Vienna City Administration, 2014).

Innovative solutions are being developed within the framework of the EU-GUGLE project and are to be replicated in the second project phase within other Viennese districts. Summary for all Participating Districts 
The energy efficiency and climate protection programs in each pilot city have been developed over a long period of time and are incorporated into each city's master plan. The timeline for reaching the energy efficiency and climate protection goals ranges between short, medium and long-term periods depending upon the individual pilot city.

All pilot districts are combining energy efficiencies in residential, municipal and educational buildings together with the innovative expansions of already existing renewable energy networks, and are promoting more onsite renewable energy generation on a large-scale by using mainly solar thermal and photovoltaic systems. Public and bicycle transport systems, e-mobility, as well as urban energy infrastructures such as district heating networks and public lighting, are being overhauled in order to reduce greenhouse gas emissions, to meet energy efficiency targets from various sectors and to support a better quality of urban living. Tenant and homeowner participation in the decision-making process for the building renovations is a key factor and promoted by different participation schemes in each city.

Programs outside of the EU-GUGLE project at European, federal, provincial, or municipal levels, such as the Covenant of Mayors (Covenant of Mayors, 2009), Mayors Adapt (Mayors Adapt, 2015), or Smart City initiatives such as ECO2 and Smart City Wien (City of Tampere, 2013; Vienna City Administration, 2014), complement the measures in each district making each EU-GUGLE contribution a part of a larger system.

The successful implementation of the energy efficient building renovation measures paired with integrated renewable energy production and distribution are dependent upon the support and participation by very different stakeholders: inhabitants, homeowners, local businesses, researchers, design professionals, construction trades, city councils and local utilities as well as regional promotion schemes. The involvement of the general public is encouraged in each participating district through various information campaigns such as direct mail, energy efficiency workshops, direct real-time feedback on energy usage, and consultations.

\section{Implemented Methodologies towards the Sustainability Roadmaps}

Each city has created programs to implement the smart city concepts outlined in the previous chapters. The following chapter will detail the individual programs established in selected case studies Aachen, Tampere, and Vienna to reach their ambitious sustainability goals.

\subsection{Aachen's Sustainability Roadmap}

The Aachen City Centre Concept 2022 focuses upon intensifying information and motivation activities to further promote thermal renovations integrating renewable energy production throughout Aachen (Pflüger et al., 2015).

Renewable energy production is to be primarily generated by wind turbines, and also from the solar panels mounted on the roofs of private, educational, civic, and industrial buildings. Increased energy production through the use of highly efficient combined heat and power plants (CHPs) within industrial buildings form another part of the energy efficiency strategy (Hemmers, 2015).

\subsubsection{Integrating Renewable Energy}

A municipal solar land registry has been established to determine the potential area available for solar thermal and photovoltaic energy production on building roofs. Within the registry are residential building blocks, public, educational, and commercial buildings. The municipal utility, STAWAG, is already cooperating with the City of Aachen to harvest solar energy using photovoltaic arrays on school roofs and other municipal buildings. The Aachen district heating network is being expanded to supply heat from CHPs to public buildings, homeowners, and commercial buildings in the city center. The current district heating power plant is coal-powered and is located on the outskirts of Aachen. The district heating network is also being expanded to supply some EUGUGLE buildings in the Aachen North pilot district. Some pilot areas are connected to a local CHP system based on heat pumps. The heat within the wastewater canal is absorbed by central heat pumps supplying a separate local low-exergy heating network. Large heat exchangers collect the heat from the municipal sewer; the heat is transported to five decentralized heat pumps in several interconnected buildings to supply heat on at required temperature levels for room and domestic hot water heating. Feasibility studies are being conducted to determine if the network can be expanded. In one pilot area, heat supply of the current district heating and the new local heat pump network will be combined. Although there are no photovoltaic arrays on the buildings themselves, the solar energy production by several photovoltaic plants are being considered on either buildings owned by STAWAG or on municipal buildings in the direct neighborhood (Hemmers, 2015).

\subsubsection{Social Sustainability}

Social housing and cultural buildings are to be thermally refurbished as part of the social sustainability strategy in Aachen. The higher living comfort provided by the thermal refurbishments is being made available to marginalized and lower income families who normally cannot afford the renovations. The tenants are involved in the advising process and receive individual consultation about energy-conscious behavior to maximize their indoor comfort while simultaneously conserving energy. The tenants in the participating buildings are informed at regular intervals of the progress of the renovations and celebrate the milestones together with the other project stakeholders. The City of Aachen, together with the altbau plus Association, 
and the Consumer Advisory Board forms the Innovation Vouchers Working Group. The working group has developed a process to launch Innovation Vouchers, a financial subsidy for tenants and homeowners to receive onsite advice about how to reduce their energy consumption through using innovative technologies to meet the sustainability goals (Hemmers, 2015).

\subsubsection{Energy Conservation Measures}

The heating systems in the pilot buildings are being centralized and replaced with highly efficient heating systems partly based on renewable energies. Some of the existing buildings contain inefficient individual room heaters and others have individual heating boilers for single apartments. Tenants living in these apartments have previously selected individual rooms to heat for short periods instead of heating the whole apartment as heating costs are prohibitively high in the buildings prior to renovation due to high heat losses through the poorly insulated exterior envelopes. As part of the renovation measures, the building envelopes are being insulated of the non-designated buildings for building conservation. In one case study building, thermal insulation was only possible on the inner courtyard side due to building preservation regulations. In all buildings, the attic floors and cellar ceilings are receiving additional insulation, while windows are being replaced with higher efficiency double and triple-glazed panes. In two areas, replacing the apartment balconies has eliminated thermal bridges. In some buildings, heat recovery in the mechanical ventilation system has been installed. Lighting in public areas is being converted to LED bulbs (Hemmers, 2015).

\subsection{Tampere}

EU-GUGLE is one of several complementary projects within the City of Tampere, which focuses on energy efficiency. Together, the projects are realizing the sustainability goals throughout the city. The local utility strives to increase renewable energy production without subsidies. An important aspect of Tampere's sustainability approach is to report actual energy and cost savings through a centralized monitoring system to different stakeholders, including the inhabitants. The following sections outline the sustainability measures included within the Tammela pilot project.

\subsubsection{Integrating Renewable Energy}

Tampere has a large-scale centralized municipal district heating network with CHP that covers the densely built city area and also partly extends into neighboring districts. The local power utility, which provides and operates the district heating network, has increased the share of renewable energy production in their own facilities from 10 percent in 2010 to 30 percent in 2015. This has been a major influence to the positive climate turnaround that Tampere has been able to reach in the preceding years. All Tammela pilot buildings are connected to the district heating network. Single-family houses in lower density areas are also producing and using more and more site-specific renewable energy. Heat is primarily produced from ground heat sources and photovoltaic panels produce electricity.

\subsubsection{Social Sustainability}

As the pilot buildings and building sites are privately owned, the homeowners have formed privately owned housing co-operatives and/or limited liability housing companies. The individual homeowners are essential in the entire decision-making process for the building renewals. The participants involved in the Tammela pilot project are committed to reaching the goals of sustainability and energy efficiency. The sustainability goals can only be reached when the majority of homeowners in the apartment buildings work collectively to decide upon the extent of the thermal renovations, the types of building services installed in the buildings, and also individual energy use behavior. The process leads to collaborative efforts to meet the goals, where the homeowners support each other. Guidance is provided to both the housing companies and the inhabitants on how to conserve energy (City of Tampere, 2013).

\subsubsection{Energy Conservation Measures}

A strongly cohesive Finnish culture leads to cooperation towards sharing heating costs, maintenance, and repairs in residential apartment buildings. This cultural background provides the best possible foundation for energy efficiency improvements because it leads to decisions supporting the most effective energy efficiency measures: upgrading the overall building envelope together with technical service systems or installing completely new systems. The heating systems are centralized and all housing companies are connected to the district heating network. The electric supply is conventional. The extensive building renovations are being performed in close collaboration with the residents, housing company boards, and property managers to minimize disruptions to the tenants during the construction process (Heidenreich et al., 2014). The EUGUGLE pilot buildings have invested in improving heating and ventilation systems. Typical measures have been installations of exhaust air heat pumps with state of the art real-time energy management systems, the adjustment of heat distribution to individual apartments, and windows with integrated passive ventilation. Exhaust air heat pumps have been shown to be the most significant measure to conserve energy. $20 \%$ to $45 \%$ of heating energy consumption can be reduced despite higher electricity consumption by the equipment. However, the potential energy savings are highly dependent upon the occupants' interaction with the new 
heating and ventilation equipment. Thus, the training program for energy-conserving behavior is very important for reaching the energy conservation goals. Feedback to the stakeholders is given in both comparative costs and energy consumption to give an overview of the entire energy system to the utility company and the building managers illustrating the direct impacts of occupant behavior on energy use in realtime.

\subsection{Vienna's Sustainability Roadmap}

The activities within the EU-GUGLE project align with the Smart City Vienna objectives as outlined in the Smart City Wien Framework Strategy, a long-term plan to 2050 for urban development integrating energy, mobility, buildings, and infrastructural developments to move towards the goal of an intelligent city, which combines the key aspects of Resources, Innovation and Quality of Living (Vienna City Administration, 2014). The vision of Vienna as an intelligent city uses innovative solutions based upon information and communications technologies (ICT) that allow higher transparency for sustainable development while minimizing overall consumption of resources. The goals are to reduce per capita greenhouse gas emissions by $35 \%$ by 2030 and by $80 \%$ by 2050 compared to 1990 levels (Vienna City Administration, 2014). The purpose of the intelligent city is to support the high quality of life for all inhabitants maintaining Vienna as one of the world's most livable cities (Mercer LLC, 2015). EU-GUGLE is one of the several projects working towards achieving the goals of the Smart City Wien Framework Strategy.

\subsubsection{Integrating Renewable Energy}

Individual households in Vienna are able to select up to $100 \%$ renewable electricity production from various providers. The city offers financial incentives for solar thermal and photovoltaic installations. However, agreements with the majority of building inhabitants and shared costs need to be agreed for each apartment prior to building installation. A Multi-Active Façade has been designed for one of the participating housing estates in Penzing. The Multi-Active Façade is a specially designed pre-fabricated highly insulated wall panel system incorporating semi-transparent photovoltaic cells, room-based ventilation with heat recovery, and triple-glazed passive house quality windows (Treberspurg, 2016). The electricity generated from the photovoltaic modules will be used to power the mechanical ventilation system with heat recovery and will be the power supple for lighting shared areas in the building.

\subsubsection{Social Sustainability}

More than 400,000 social housing dwellings in Vienna are owned by both the City of Vienna and social housing corporations (Vienna City Administration, 2014). The housing complexes are distributed throughout the city mixed together with privately owned homes. The tenants within the subsidized housing complexes are people from different demographic backgrounds making the social housing complexes safe and pleasant places to live. Urban mobility is ensured by the extensive public transit network which consists of $1,128 \mathrm{~km}$ of underground, bus and tram lines reaching all corners of the city (Himpele, 2015). Public transit is subsidized and is extensively used. Many citizens do not own cars, as reflected in the private car density of 380 cars per 1000 inhabitants (Himpele, 2015). Some pilot buildings in the Viennese EU-GUGLE project are privately owned. The living conditions for the inhabitants, especially those in social housing, are improving as a result of the pilot project. The subsidies finance the necessary thermal building refurbishments that are otherwise unaffordable for the social housing tenants. New winter gardens are created from insulating and enclosing the existing balconies increasing the total usable floor space in the refurbished apartments. The previously unused attic spaces in some of the buildings are being converted into new apartments increasing both the urban density and the total usable space in the apartment building. The increased income from the new apartments partially finances the renewals for the building. All stakeholders, including the tenants of the social housing complexes, are participating in the renewal process.

\subsubsection{Energy Conservation Measures}

Vienna is in the process of implementing cost-optimized zero-energy building standards for all construction including new construction, additions, and refurbishments (Vienna City Administration, 2014). Innovative highly energy-efficient building services, especially heating systems, are required in order to meet the goal of reducing heating, ventilation, and air conditioning (HVAC) energy consumption by $1 \%$ per capita and year. Thermal building renewals within the Viennese pilot projects insulate the exterior envelope, install highperformance double and triple-glazed windows, and upgrade current building services to reduce energy for heating and domestic hot water. Other measures include replacing lighting with LED lighting and installing elevators with energy recovery.

The renovation measures in the demonstration buildings are also sponsored by Vienna's Thewosan program, a promotion scheme for improving the energy-efficiency of existing buildings through thermal refurbishment, upgrading HVAC equipment, and introducing other innovative technologies for reducing greenhouse gas emissions (Wohnfonds Wien, 2015).

Initial tests have shown that retrofitting the Multi-Active Façade panels in front of the existing walls can reduce operational energy by up to $90 \%$ (Treberspurg, 2016). A high-efficiency ventilation system with heat recovery 
ensures a constant hygienic air change rate for maintaining very good indoor environmental quality within the refurbished apartments without drafts or heat losses. The extensions of the balcony slab are incorporated into the insulated thermal envelope with the transformation of the balconies into winter gardens, thereby reducing the heat losses through thermal bridges. Prefabrication has several advantages, including reduced construction costs and minimal disruption, as the time on site to execute the thermal refurbishment is reduced from several months to two days per apartment. Prefabrication is not only more economical than traditional construction but also allows the tenants to remain in their homes during the short installation period.

\section{Preliminary Results from the Derived Measures}

The following section will show specific building examples of energy-efficient refurbishments integrating onsite renewable energy production in the selected case studies of Aachen, Tampere, and Vienna. The refurbishments are either under construction or have been recently completed.

\subsection{Aachen}

The majority of the EU-GUGLE residential buildings in Aachen are historically listed buildings. The older pilot buildings do not have centralized heating systems, but rather individual oil or coal-based room heaters. The transition to central heating includes a major installation of hot water radiators with thermostatic radiator valves. The heating system overhaul increases the number of heated rooms in the apartments and much better heating regulation. The inhabitants can not only regulate, but also view their own heating energy consumption with new meters being installed in the apartments. The central heating systems differ in each building. As part of the building renewals, the buildings will either connect to a local heating network based on heat pumps or the municipal district heating network.

The thermal building renewals of A_RES_B2 are currently underway. The historically protected housing complex has five low-rise blocks with 148 apartments and a total conditioned gross floor area of $17,778 \mathrm{~m}^{2}$. The heating energy demand prior to the renovations ranges from $248 \mathrm{kWh} / \mathrm{m}^{2} /$ year to $277 \mathrm{kWh} / \mathrm{m}^{2} / \mathrm{year}$. After the renovations, the heating energy demand has been calculated to be $73.7 \mathrm{kWh} / \mathrm{m}^{2} /$ year. Measures to reduce building energy use include insulating the basement ceiling, attic floor, and rear façade. Due to the historical significance of the building, the other exterior walls could not be insulated. Triple-glazed windows, LED lighting and a new centralized heating system connected to the district heating network and the heat pump local network complete the efficiency measures. The main entrance to the housing complex prior to and after the renovations is visible in Figure 7.
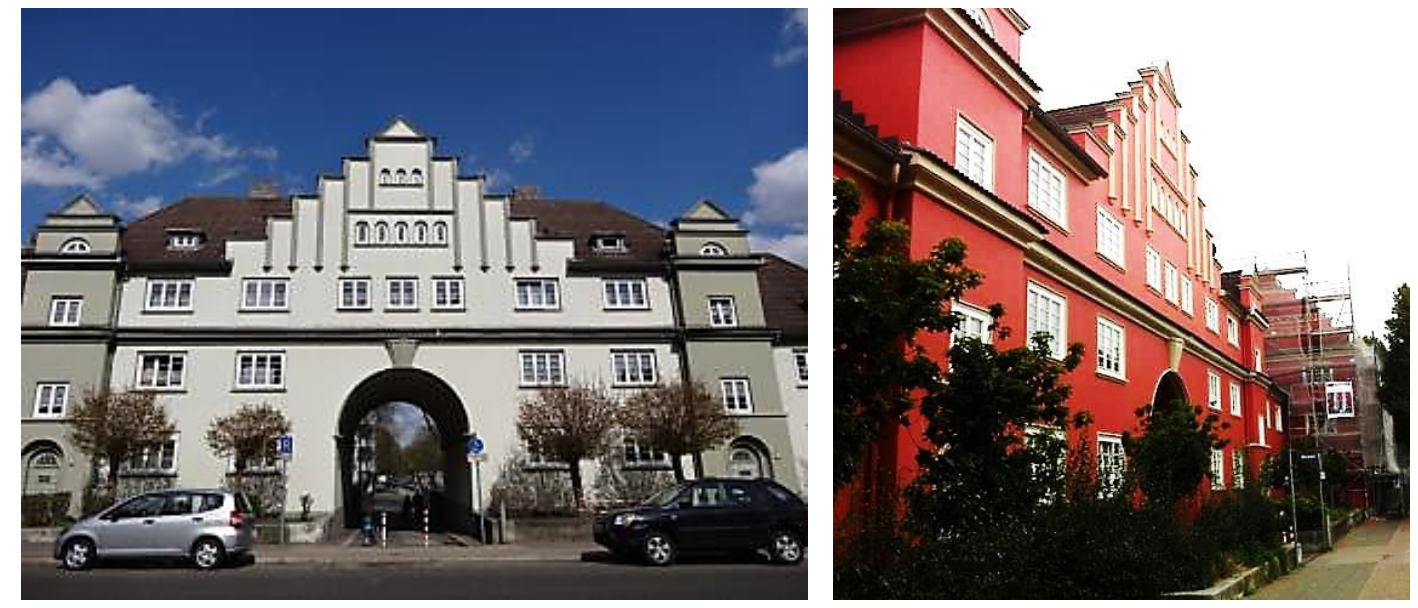

Figure 7: A_RES_B2 before renovation (left), and after renovation (right) (City of Aachen, 2013, 2015b).

\subsection{Tampere}

The first finished pilot in Tampere is a prefabricated panel residential high-rise building built in the 1980s. It has 54 owner-occupied apartments with a total heated gross floor area of $4,117 \mathrm{~m}^{2}$. Because the building condition assessment determined that the façade is in good condition, the refurbishment measures mainly focused on upgrading the heating and ventilation systems, replacing doors and windows, and installing sensor-based LED-lighting systems. Water-saving faucets were installed in the kitchens and bathrooms reducing hot water use. Two exhaust air heat pumps, $10 \mathrm{~m}^{2}$ of solar collectors and new heat exchangers have been installed. The renovations were completed in the summer of 2014. This building and all the Tampere pilots have remote building energy monitoring systems (BEMs). The advantages of the BEMs are both technical and social. The Chair may convince other residents that the investment has been worthwhile. In addition, measured energy savings have played an important role in communicating the amount of energy and water saved marketing the concept in the neighborhood. Figure 8 shows the building after renovation. The effects of the combined measures were simulated prior to commencing the refurbishment. The purchase heating energy demand was reduced to $32 \mathrm{kWh} / \mathrm{m}^{2} /$ year. 


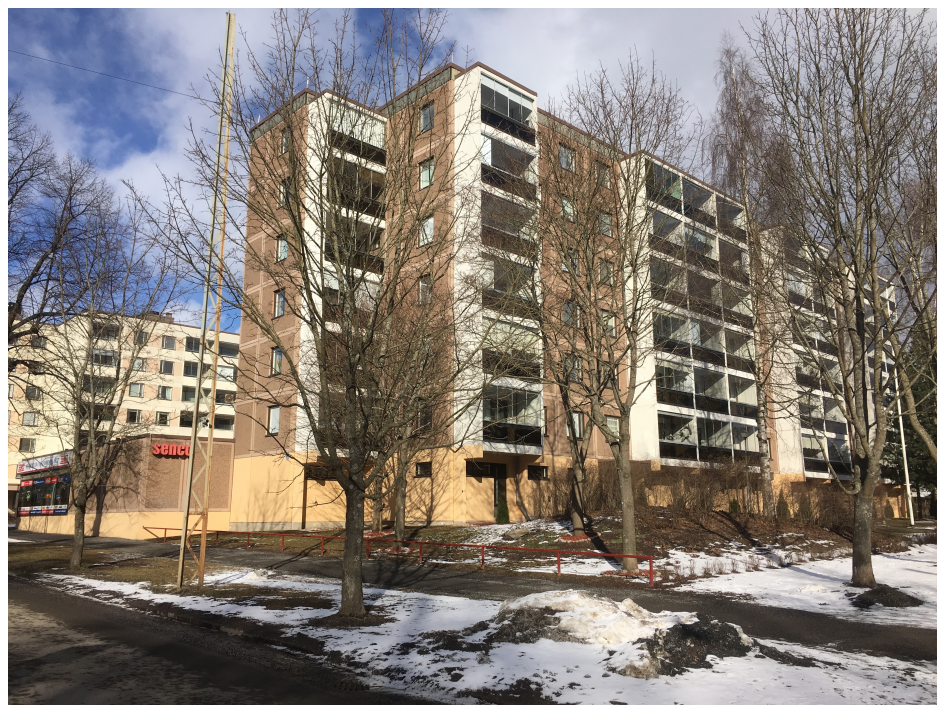

Figure 8: Demonstration building T_RES_TAM 7 (City of Tampere, 2015).

\subsection{Vienna}

Thermal building renovations are the primary means to meet the goals of reducing energy consumption and greenhouse gas emissions in Vienna. The residential low-rise building, V_RES_BOKU_2 was built in 1979 and has 24 apartments with a total conditioned gross floor area of $3,100 \mathrm{~m}^{2}$. Two new stories of apartments were constructed at the attic level during the refurbishment and are being sold privately. The proceeds of the apartment sales partially financed the thermal renovations. The entire building envelope has been insulated including new triple-glazed windows and doors, and an insulated noggin piece installed on the roof. New elevators with energy recovery were installed increasing accessibility within the building while reducing energy consumption. The building prior to and after refurbishment is seen in Figure 9. A thermal bridge analysis was conducted during the design-development process to help determine the insulation detailing. Daylight simulations and lighting optimization were also conducted during the planning process prior to installing the LED-lighting. The heating energy demand was reduced from $72.8 \mathrm{kWh} / \mathrm{m}^{2} /$ year to $26.2 \mathrm{kWh} / \mathrm{m}^{2} / \mathrm{year}$. The renovations were completed in 2014.
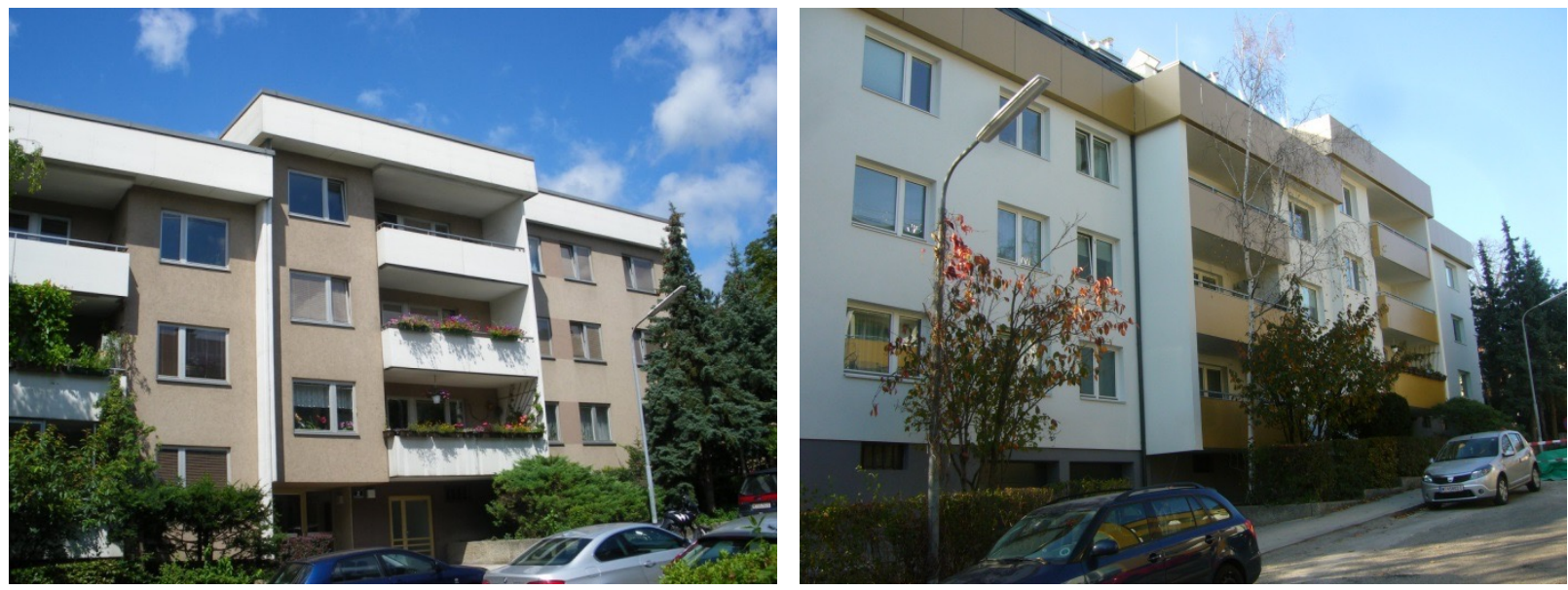

Figure 9: V_RES_BOKU2 before renovation (left), and after renovation (right) (Heidenreich, 2014, 2015).

All mentioned buildings undergo building monitoring to better understand whether the calculated performance indicators have been reached.

\section{6. $\quad$ Next Steps}

\subsubsection{Aachen}

Aachen will continue to refurbish the building stock of the demonstration sites at an accelerated rate to double or triple the amount of thermally refurbished buildings in comparison to the national average. A study has been conducted to assess the feasibility of installing photovoltaic arrays on the flat roofs of educational and industrial buildings. The installation photovoltaic arrays throughout the city on flat roofs will increase the amount of local renewable energy production and will be connected to the municipal electricity grid (Heidenreich et al., 2015). To complement the energy efficiency refurbishments in the buildings, tenant 
consultations and workshops to train and evaluate energy-conscious behavior are taking place (Hemmers, 2015).

\subsubsection{Bratislava}

Feasible solutions foreseen in the urban areas of the city districts include photovoltaic, solar collectors for hot water preparation, and heat recovery. These technologies will be applied in all involved buildings. In addition, heat pumps are considered, but need to be approved by the local authorities (Heidenreich et al., 2014).

The demonstration buildings in Bratislava are in the planning process, and will perform thermal renovations coupled with innovative HVAC systems. Each site has been assessed according to the building construction type and the exterior building envelopes are to be insulated with thermal insulation composite systems. All windows are to be replaced with triple-glazed panes with external solar shading. Heat pumps with heat recovery will provide space heating and meet domestic hot water demands in the majority of the pilot sites with a photovoltaic array planned for one housing complex for meeting the space heating and hot water needs. The condominium owners are to receive information on how to most effectively use the new building services equipment and solar shading.

\subsubsection{Milan}

The childcare center will be retrofitted using prefabricated integrated elements with a high level of thermal insulation and air tightness. Automated solar shading during the day, and summer natural night ventilation via automated windows and two added stack flow elements provide summer comfort without active cooling. The building will fulfill the definition of a nearly zero energy building (NZEB), and will be one of the first examples of a NZEB retrofit in Italy (Causone, Carlucci, Moazami, Cattarin, \& Pagliano, 2015; Causone, Moazami, Carlucci, Pagliano, \& Pietrobon, 2015; Pagliano et al., 2016).

The social housing blocks will also undergo an ambitious deep renovation, though not to the NZEB level. They will be important benchmarks for future activities from technical, organizational, and financial points of view. It was impossible to apply double flow ventilation on the largest social housing building block because of space limitations. Therefore, an alternative way of recovering energy from the exhaust air has been developed. A heat pump uses the extract air as a heat source for delivering energy at low temperature for the preparation of domestic hot water. The other two apartment blocks are close to Chiaravalle Abbey and the "agriculture park". They will be integrated into a redesign of bike access to the abbey and the park for better connection to the district and the city. White roofs and greening are being analyzed as means for reducing the heat island effect. Thermal energy for heating will be generated efficiently in the Linate cogeneration plant owned by the local A2A Energy Utility.

\subsubsection{Sestao}

The demonstration buildings for refurbishment have been constructed from 1890 to 1930 and aim to reduce energy consumption by more than $50 \%$ from the calculated original energy consumption levels. More than 200 scenarios with five different HVAC systems with and without heat recovery have been considered in whole building simulations to determine the most effective combination to reduce energy demand and consumption for reaching the energy savings targets. None of the demonstration buildings in the base case scenarios have central heating systems and most have rudimentary heaters such as small electric radiators or butane heaters to provide minimal heat in winter. The thermal renovations are improving the efficiency of the building envelopes by increasing insulation levels and replacing windows with higher thermal values. Innovative technologies considered for the demonstration buildings include the use of biomass boilers combined with high energy efficiency ratio (EER) chillers and heat recovery, ground source and high-efficiency heat pumps with heat recovery. The majority of these apartment buildings are either unoccupied or occupied by elderly or immigrant owners. Sestao has established an innovative procedure for carrying out the thermal refurbishments with upgraded building services for apartment buildings. The solution has been developed by Sestao Berri 2010 and is innovative for residential renovations in Spain. The renovation plan is carried out in five stages (Heidenreich et al., 2014):

1. Sestao Berri 2010 purchases both unoccupied and occupied flats from owners who are willing to sell in an apartment building.

2. The first phase of the thermal building renovations with upgraded building systems begin in the unoccupied flats.

3. The tenants who decide to remain in their apartments are temporarily relocated to the newly renovated flats in the apartment building at no cost to the tenants. The tenants are financially compensated with a basic income during the renovations.

4. The second renovation phase begins upon completion of the first phase. Upon completion of the thermal renovations, the formerly unoccupied flats are then put on the market to be sold as social housing, and the tenants move back into their original flats.

5. The sale of the flats as social housing finances the building renovation costs. 
The renovation process has been designed to provide the least inconvenience for building inhabitants while simultaneously providing a source of financing for the construction works. All apartment buildings in Sestao participating in the EU-GUGLE project will follow the five-stage renovation process for thermally upgrading the building envelope coupled with an innovative building services installation.

\subsubsection{Tampere}

In order to celebrate Finland's centenary, Finland has decided to meet the EU's 20-20-20 goals for 2020 three years early in 2017 (Finnish Ministry of the Environment, 2010). The City of Tampere aims to be a resourceefficient and low carbon smart eco-city. It is expected that consumers and businesses through their consumption decisions will lead the free market to become more efficient when using energy in Tampere. All measures form a part of the "energy-smart built environment" vision for Finland that creates "an energyefficient, low-emission, high quality built environment that employs all necessary means to mitigate climate change" (Finnish Ministry of the Environment, 2010). The vision includes five different areas: building, energy, waste, transport and services (utilities) for meeting the goals of the energy-smart built environment (Heidenreich et al., 2015).

\subsubsection{Vienna}

Three large-scale social housing projects are in the advanced planning stage and are scheduled for construction tendering later this year. Coupled with one large social housing block is the multi-active façade, an innovative research project using pre-fabricated panels that is part of the City of the Future federal research scheme (Treberspurg, 2016). Four smaller apartment buildings are at an earlier design phase, and the process used for the completed pilot project is applied to these buildings. The innovative solutions being developed within the framework of the EU-GUGLE project will be replicated in the second project phase within other Viennese districts.

\section{Discussion}

Even though the 20-20-20 goals by the European Union are quite clear about the desired objective, and the general methodology within EU-GUGLE to meet the objectives is the same in all pilot districts, the resulting solutions are different due to secondary aspects and varying framework conditions that influence each city. Factors such as the existing ownership models for the pilot buildings (i.e. private versus public ownership), the existing condition of the buildings along with the construction typology, the chosen upgrade of the external envelope, the selected HVAC and RES technologies, available financial incentives, municipal regulations, and the condition of the surrounding infrastructure all influence the project outcomes.

The involvement of the varied stakeholders is a key element to the project. Meticulous planning including state of the art whole building simulations still cannot accurately predict the actual energy consumption by the residents and homeowners as occupants can change their behavior as they adapt to the building technologies and to the higher comfort levels. Cooperation with the homeowners and tenants to tailor the energy efficiency solutions to suit their requirements has been recognized in this project in order to best meet the ambitious sustainability goals. The involvement of the occupants during the planning and post-occupancy stages gives each person involved a greater sense of belonging, and motivation to meet the collective goal of energy savings by adapting their own behavior. Studies have shown that energy-related occupant behavior can cause energy consumption to exceed initial predictions by up to a factor of three (Polinder et al., 2013), but that cohesion to a group with strong leadership can be a strong positive influence on energy-conserving behavior (European Environment Agency, 2013).

Quantitative feedback about the effectiveness of the chosen measures through different building monitoring applications is important for all stakeholders. The building monitoring systems provides feedback for stakeholders who do not usually have access to data regarding the effectiveness of the solutions, such as designers and researchers. Greater involvement by the local governments to create a sustainability framework with financial incentives for innovations in research and creative renovation solutions is enhancing the effectiveness of the project and influences the pace of refurbishment.

\section{Future Research Directions}

More research is needed about the actual long-term impact of residential energy-related occupant behavior on the total energy consumption of buildings. Many simulations and models of energy-related occupant behavior can be found in the literature, however, long-term access to residential energy use data is difficult to obtain and the predicted energy consumptions in the models are often more optimistic than actual measured values (Andersen, 2009; Branco, Lachal, Gallinelli, \& Weber, 2004; Wei, Jones, \& de Wilde, 2014). The energy use data from building monitoring in each demonstration district can not only help the building users directly but also improve the general body of knowledge about the interaction of people with new and efficient HVAC systems in residential and institutional buildings on a large scale. The building monitoring systems can also help to verify the extent of the effectiveness of the different measures used to promote energy-efficient behavior. Quantitative data showing the extent to which the goals of energy-efficient behavior change have 
been met within the energy efficiency directive (European Commission, 2012) can also be measured to determine the effectiveness of the directive.

\section{Conclusions}

An overview of the activities within the EU-GUGLE demonstration project has been presented illustrating how the integrated approaches involving different stakeholders in the six partner cities are working together to sustainably revitalize approximately $200,000 \mathrm{~m}^{2}$ of the mature building stock and the urban infrastructure on a district scale. The approach focuses upon improving energy efficiency, decreasing energy consumption, while increasing the portion of innovative HVAC and RES systems. The sustainability goals of the European Union have been aligned with each city's sustainable master plan despite the challenges of very different building traditions, cultures, climates, and political structures in each country. The success of the project is due to the knowledge exchange and integrated efforts of the dedicated stakeholders within each EU-GUGLE pilot. Parallel efforts in related projects within each city help each partner city to move closer to the goals of the European Commission's Smart Cities and Communities Initiative: to reduce primary energy consumption by $40 \%$ to $80 \%$ and increase renewable energy use by $25 \%$ through nearly zero energy building renovation models by 2020 . The pilot projects' results are being extended within the replication cluster as the knowledge, experience, and technical innovations gained within the EU-GUGLE pilot cities are shared within the campaign to the associated cities and abroad via the replication cluster (youris.com European Research Media Center, 2016).

\section{Acknowledgements}

EU-GUGLE stands for "European cities serving as Green Urban Gate towards Leadership in sustainable Energy" and is funded under the $7^{\text {th }}$ Framework Program for Research and Technological Innovation. It is coordinated by CENER, Spain's National Center for Renewable Energies.

\section{References}

Andersen, R. V. (2009). Occupant Behaviour with regard to Control of the Indoor Environment. Copenhagen, Denmark: Technical University of Denmark (DTU).

Arkkitehdit MY. (2015). Keskustahanke (pp. Possible center of Tampere in 2030). Tampere, Finland: City of Tampere.

Branco, G., Lachal, B., Gallinelli, P., \& Weber, W. (2004). Predicted versus observed heat consumption of a low energy multifamily complex in Switzerland based on long-term experimental data. Energy and Buildings, 36(6), 543-555. doi:http://dx.doi.org/10.1016/j.enbuild.2004.01.028

Causone, F., Carlucci, S., Moazami, A., Cattarin, G., \& Pagliano, L. (2015). Retrofit of a Kindergarten Targeting Zero Energy Balance. Energy Procedia, 78, 991-996. doi:http://dx.doi.org/10.1016/j.egypro.2015.11.039

Causone, F., Moazami, A., Carlucci, S., Pagliano, L., \& Pietrobon, M. (2015). Ventilation strategies for the deep energy retrofit of a kindergarten. Paper presented at the 36th AIVC Conference " Effective ventilation in high performance buildings", Madrid, Spain. http://www.aivc.org/sites/default/files/94_0.pdf

City of Aachen. (2013). A_RES_B2 before renovation. Aachen, Germany: City of Aachen.

City of Aachen. (2015a). Aachen Nord Smart City District. Aachen, Germany: City of Aachen.

City of Aachen. (2015b). A_RES_B2 after renovation. Aachen, Germany: City of Aachen.

City of Bratislava. (2013). Akčný plán udržatel'ného energetického rozvoja Hlavného mesta SR Bratislavy. In E. C. Bratislava (Ed.), (pp. 1-61). Bratislava, Slovakia: City of Bratislava.

City of Tampere. (2012). Tampereen kaupunki: Pormestareiden ilmastositoumuksen Kestävän energiankäytön ohjelma. Retrieved from Tampere, Finland: http://www.tampere.fi/liitteet/k/XOLoJQ5XQ/Kestavan_energiankayton_ohjelma.pdf

City of Tampere. (2013). The First 3 Years: ECO2 - Eco-Efficient Tampere 2020. Retrieved from Tampere, Finland: $h$ ttp://www.e-julkaisu.fi/tampereen_kaupunki/ECO2-project/first_3_years/

City of Tampere. (2015). T_RES_TAM_7. Tampere, Finland: City of Tampere.

City of Vienna. (2016). Wien 14., Penzing. Vienna, Austria: City of Vienna.

Covenant of Mayors. (2009). Covenant of Mayors. Retrieved from Brussels, Belgium: http://www.covenantofmayors.eu/IMG/pdf/covenantofmayors_text_en.pdf

DIRECTIVE 2012/27/EU OF THE EUROPEAN PARLIAMENT AND ŌF THE COUNCIL of 25 October 2012 on energy efficiency, amending Directives 2009/125/EC and 2010/30/EU and repealing Directives 2004/8/EC and 2006/32/EC, (2012).

European Commission. (2015, April 15, 2016). 2020 climate and energy package. September 15, 2015. Retrieved from http://ec.europa.eu/clima/policies/strategies/2020/index_en.htm

European Environment Agency. (2013). Achieving energy efficiency through behaviour change: what does it take? (5/2013). Retrieved from Luxembourg: http://www.eea.europa.eu/publications/achieving-energyefficiency-through-behaviour/at_download/file 
Faludi, A. K. F. (2015). The "Blue Banana" Revisited. European Journal of Spatial Development, 1-26.

Finnish Ministry of the Environment. (2010). ERA 17: For an energy-smart built environment 2017. In Finnish Ministry of the Environment (Ed.), (pp. 1-16). Helsinki, Finland: Finland Ministry of the Environment, SITRA Finnish Innovation Fund, Tekes Finnish Funding Agency for Innovation.

Garbisu, A. (2016). Area de Actuacion (Vol. 1.4 MB, pp. EU-GUGLE District for Refurbishment in Sestao). Sestao: Sestao Berri.

Grünner, R. (2016). Bratislava's EU-GUGLE Districts Google Maps (Vol. 887 kB). Bratislava, Slovakia: Google Maps.

Heidenreich, M. (2014). V_RES_BOKU2 before renovation. Vienna, Austria: University of Natural Resources and Life Sciences, Vienna.

Heidenreich, M. (2015). V RES BOKU2 after renovation. Vienna, Austria: University of Natural Resources and Life Sciences, Vienna.

Heidenreich, M., Corradino, G., Grünner, R., Hemmers, R., Sahakari, T., Vankann, M., . . Morishita, N. (2015). Deliverable 4.6 - Smart renovation strategies for each model and associated city. Retrieved from Vienna, Austria:

Heidenreich, M., Palos, S., Serna, F., Hemmers, R., Pagliano, L., \& Sternova, Z. (2014). Deliverable 2.1.4 1 st Feasability Study of Forseen Buildings Integrated RES Including Organisational Forms and Interfaces. Retrieved from Vienna, Austria:

Hemmers, R. (2015). Status of Smart District Aachen 4th Technical Committee Meeting. Vienna, Austria: Synergiecomm.

Himpele, K. (2015). Vienna in Figures M. Lukacsy \& C. Fendt (Eds.), (pp. 1-24). Retrieved from https://www.wien.gv.at/statistik/pdf/viennainfigures.pdf

Hospers, G.-J. (2003). Beyond the Blue Banana? Intereconomics, 38(2), 76-85. doi:10.1007/BF03031774

Manteca, F. G. (2015). Project - EU-GUGLE. September 15, 2015. Retrieved from http://eu-gugle.eu/project/

Mayors Adapt. (2015). Mayors Adapt Initiative. October 10, 2015. Retrieved from http://mayors-adapt.eu

Mercer LLC. (2015). Vienna Tops Latest Quality of Living Rankings. October 20, 2016. Retrieved from http://www.uk.mercer.com/newsroom/2015-quality-of-living-survey.html

Official Statistics of Finland. (2016). Preliminary population statistics, Tampere. Retrieved from Helsinki: http://www.stat.fi/til/vamuu/index en.html

Pagliano, L., Armani, R., Sangalli, $\bar{A}$., Causone, F., \& Pietrobon, M. (2016). Analysis of ventilation strategies for the nearly zero energy retrofit of a day care center. Unpublished conference paper. Dipartimento di Energia, eERG research Group. Politecnico di Milano. Aalborg, Denmark.

Pflüger, H. J., Pflüger, F., Lemaire, A., Engel, F., \& Ruppert, A. (2015). Innenstadtkonzept 2022: Entwicklungsperspektiven für die Aachener Innenstadt. Retrieved from Aachen, Germany: http://www.aachen.de/de/stadt_buerger/planen_bauen/stadtentwicklung/innenstadt/innenstadtkonzept_202 2/Innenstadtkonzept-.pdf

Polinder, H., Schweiker, M., van der Aa, A., Schakib-Ekbatan, K., Fabi, V., Andersen, R. V., ... Wagner, A. (2013). Final Report Annex 53, Volume II Occupant Behavior and Modeling. Retrieved from Tohoku: http://www.iea-ebc.org/index.php?id=141

Sangalli, A. (2016). Milan's EU-GUGLE Districts Rogoredo and San Guilia Google Maps: Google Maps.

Sestao Berri S.A. (2016a). European projects I Sestao Berri. Retrieved from http://sestaoberri2010.com/projects/european-projects/

Sestao Berri S.A. (2016b, 2016). Sestao Berri. Retrieved from http://sestaoberri2010.com/en/

Stadt Aachen. (2012). Aachen* 2030 Masterplan: Perspektiven und Impulse für die räumliche Entwicklung der Stadt Aachen. Retrieved from Aachen, Germany: http://www.aachen.de/de/stadt_buerger/planen_bauen/_materialien_planen_bauen/stadtentwicklung/stadt/ aachen2030/masterplan/AC2030_beschlossen_masterplan_lowres.pdf

Treberspurg, M. (2016). Multi-Active Facade. Stadt der Zukunft. April 29, 2016. Retrieved from http://www.hausderzukunft.at/results.html/id7522

Vankann, M. (2015). Aachen Germany Adaptation Activities. Retrieved from Adaptation Strategy Climate Change Adaptation Concept website: http://mayors-adapt.eu/wp-content/uploads/2015/07/Aachen.pdf

Vienna City Administration. (2014). Smart City Wien Framework Strategy: Overview Smart City Wien, Vienna City Administration (Ed.) ( $p$. 1-24). Retrieved from https://smartcity.wien.gv.at/site/files/2014/10/140924 KF SCW gesamt ENG.pdf

Wei, S., Jones, R., \& de Wilde, P. (2014). Driving factors for occupant-controlled space heating in residential buildings. Energy and Buildings, 70, 36-44. doi:http://dx.doi.org/10.1016/j.enbuild.2013.11.001

Wohnfonds Wien. (2015). Erstinfo - thermisch-energetisch Wohnhaussanierung. In W. Wien (Ed.). Vienna, Austria: Wohnfonds Wien.

youris.com European Research Media Center. (2016). My Smart City District. May 3, 2016. Retrieved from http://mysmartcitydistrict.eu 